Nilai Islam dan Nilai Kebangsaan...

\title{
NILAI ISLAM DAN NILAI KEBANGSAAN \\ DALAM PEMBELAJARAN BAHASA INDONESIA
}

\author{
Siti Mutmainah \\ DosenTetap PGMI INAIFAS KencongJember
}

\begin{abstract}
There are three basic patterns that can be developed in coaching imtaq and national values in school. First, imtak guidance through religious education and nationality through Civics education, as we have seen so far. Programs like this certainly have many weaknesses, because religious teachers and PK teachers are only independent. Second, integrating the values of Islam and nationality in each subject, while still making the teacher of religion and $\mathrm{PK}$ as central to the formation of imtaq and nationality. Third, is to empower all potential teachers to jointly develop the values of imtaq and nationality through the learning process in each field of study. This pattern has many advantages, because every teacher in the field of study has the same vision and mission.
\end{abstract}

Keywords:Islamic Value, National Value, Indonesian Language

\section{PENDAHULUAN}

Perkembangan dunia global bukan hanya menghasilkan produktivitas manusia dalam mempermudah cara hidupnya, namun telah berakibat buruk terhadap pola dan tata hubungan kemanusiaan. Misalnya kehadirian internet di satu sisi telah memberi nilai tambah informasi namun di sisi lain telah pula mendorong tumbuhnya tindakan destruktif di masyarakat. Bahkan dari berbagai kemajuan muncul dekadensi moral yang mengglobal juga saat ini.

Dekadensi moral terjadi karena berbagai faktor, antara lain:

1. Kurang tertanamnya jiwa agama pada tiap-tiap orang dalam masyarakat.

2. Keadaan masyarakat yang kurang stabil, baik dari sisi ekonomi, sosial dan politik.

3. Pendidikan moral tidak terlaksana sebagaimana mestinya, baik di rumah, sekolah,

4. maupun di masyarakat.

5. Suasana rumah tangga yang kurang harmonis.

6. Diperkenalkannya secara populer berbagai obat dan alat anti kelamin.

7. Banyaknya tulisan, gambar, siaran, kesenian yang tidak mengindahkan dasardasar 
Siti Mutmainah

8. tuntunan moral.

9. Kurang adanya bimbingan untuk mengisi waktu luang dengan cara yang baik, dan

10. yang membawa pada pembinaan moral.

11. Tidak ada atau kurangnya markas-markas bimbingan dan penyuluhan bagi anak-anak dan pemuda. ${ }^{1}$

Hal ini bukan hanya menjadi wacana, namun hendaknya menyadarkan kita bahwa pendidikan kita belum cukup mampu membentengi generasi muda dari prilaku-prilaku destruktif yang mereka konsumsi dari berbagai sumber informasi. Pendidikan harus diarahkan pada pembinaan iman dan takwa atau moral pelajar sehingga pelajar memiliki tanggung jawab terhadap masa depan dirinya, bangsa dan negara.

Dalam konteks ini, tugas seorang guru bukan sekedar mengajar tetapi juga mendidik peserta didik. Jika hanya fokus dalam mengajar maka yang dicapai oleh seorang guru hanyalah keberhasilan membuat siswa mampu dalam bidang tertentu saja. Sedangkan dengan mendidik, selain siswa mampu dalam bidang yang diampu oleh seorang guru siswa juga dapat menjadi pelajar yang berahlak mulia.

Hal ini sejalan dengan pendidikan yang sedang dicanangkan saat ini yaitu kurikulum berbasis pendidikan karakter. Dalam pendidikan karakter diharapkanmenghasilkan insan-insan yang memiliki karakter mulia, di samping memiliki kemampuan akademik dan keterampilan yang memadai. Salah satu cara untuk mewujudkan manusia yang berkarakter adalah dengan mengintegrasikan pendidikan karakter dalam setiap pembelajaran.

Pendidikan karakter dilakukan secara terintegrasi ke dalam semua mata pelajaran. Integrasi yang dimaksud meliputi pemuatan nilai-nilai ke dalam substansi pada semua mata pelajaran dan pelaksanaan kegiatan belajar mengajar yang memfasilitasi dipraktikkannya nilai-nilai dalam setiap aktivitas pembelajaran di dalam dan di luar kelas untuk semua mata pelajaran. Setidak-tidaknya sudah ada dua mata pelajaran yang diberikan untuk membina akhlak dan budi pekerti peserta didik, yaitu Pendidikan Agama dan PKn. Namun menggantungkan pembentukan watak siswa melalui kedua mata pelajaran itu saja tidak cukup. Pengembangan karakter peserta didik perlu melibatkan semua mata pelajaran, salah satunya pembelajaran Bahasa Indonesia. Berikut dideskripsikan integrasi nilai imtaq dan kebangsaan dalam pembelajaran bahasa Indonesia.

${ }^{1}$ Darajat, Zakiah. Membina Nilai-nilai Moral di Indonesia, (Jakarta: Bulan Bintang, 1993), hal. 12

70 | FALASIFA, Vol. 9 Nomor 1 Maret 2018 


\section{Pengertian Pendidikan Karakter}

Karakter adalah watak, tabiat, akhlak, atau kepribadian seseorang yang terbentuk dari hasil internalisasi berbagai kebajikan yang diyakini dan digunakan sebagai landasan untuk cara pandang, berpikir, bersikap dan bertindak. ${ }^{2}$ Karakter mengalami pertumbuhan yang membuat suatu nilai menjadi budi pekerti, sebuah watak batin yang dapat diandalkan dan digunakan untuk merespon berbagai situasi dengan cara yang bermoral. ${ }^{3}$ Dari pengertian di atas, dapat disimpulkan bahwa karakter adalah watak, tabiat, akhlak, budi pekerti yang membentuk kepribadian dan tingkah laku yang menjadi sifat tetap dalam diri seseorang yang dapat digunakan untuk berinteraksi dengan orang lain dan lingkungan.

Pendidikan adalah suatu usaha masyarakat dan bangsa dalam mempersiapkan generasi muda bagi keberlangsungan kehidupan masyarakat dan bangsa yang lebih baik di masa depan. Keberlangsungan tersebut ditandai dengan pewarisan budaya dan karakter yang dimiliki bangsa dan masyarakat. ${ }^{4}$ Berkaitan dengan pendidikan karakter: schools, through their structural arrangements and the behavior patterns of teachers, provide pupils with certain experiences largely unavailable in other social settings, and that these experiences, by virtue of their peculiar characteristics, represent conditions conducive to the acquisition of norms. ${ }^{5} \mathrm{Benninga}$ berpendapat bahwa sekolah yang mempunyai peraturan dan perilaku guru yang baik, akan membawa siswa ke dalam pengalaman yang baik pula, dengan tempat sosial yang baik maka akan terbentuk karakter serta perolehan norma yang baik.

Pendidikan karakter adalah sistem penanaman nilai-nilai karakter kepada warga sekolah yang meliputi komponen pengetahuan, kesadaran atau kemauan, dan tindakan untuk melaksanakan nilai tersebut, baik terhadap Tuhan Yang Maha Esa, diri sendiri, sesama, lingkungan, maupun kebangsaan sehingga menjadi manusia insan kamil. ${ }^{6}$ Pendidikan karakter dalam konteks pendidikan di Indonesia adalah pendidikan nilai,yakni pendidikan nilai-nilai luhur yang bersumber dari budaya bangsa Indonesia sendiri, dalam rangka membina kepribadian generasi muda.Dalam UU Nomor 20 Tahun 2003 tentang Sistem Pedidikan Nasional

\footnotetext{
${ }^{2}$ Kemendiknas, Rencana Aksi Pendidikan Nasional Pendidikan Karakter, (Jakarta: Balitbang dan Puskur, 2010), hal.3.

${ }^{3}$ Lickona. Thomas, Pendidikan Karakter-Pandua Lengkap Mendidik Siswa Menjadi Pintar dan Baik, (Bandung: Nusa Mesia, 2013), hal.72.

${ }^{4}$ Kemendiknas, Rencana Aksi Pendidikan Nasional Pendidikan Karakter, (Jakarta: Balitbang dan Puskur, 2010), hal.4.

${ }^{5}$ Benninga, J.S, Moral, Character, And Civic Education In The Elementary School, (London: Teachers College Press, 1991), hal. 3.

${ }^{6}$ Narwanti, Sri, Pendidikan karakter, (Yogyakarta : Familia, 2011), hal. 14.
}

FALASIFA, Vol. 9 Nomor 1 Maret 2018 | 71 


\section{Siti Mutmainah}

pasal 3 merumuskan fungsi dan tujuan pendidikan nasional yang berbunyi: Pendidikan nasional berfungsi mengembangkan kemampuan dan membentuk karakter serta peradaban bangsa yang bermartabat dalam rangka mencerdaskan kehidupan bangsa. ${ }^{7}$

Berdasarkan uraian pengertian di atas, maka dapat disimpulkan bahwa pendidikan karakter adalah usaha sadar dan terencana yang dapat dilakukan baik oleh pemerintah, masyarakat, sekolah maupun orang tua untuk membentuk kepribadian dan tingkah laku seseorang sebagai landasan berpikir, bersikap dan bertindak dalam interaksinya terhadap Tuhan Yang Maha Esa, diri sendiri, orang lain maupun lingkungan. Dalam dunia pendidikan, sekolah merupakan wadah yang tepat untuk melaksanakan penanaman nilai-nilai karakter pada siswa. Penanaman nilai-nilai tersebut dapat membentuk kepribadian siswa menjadi manusia yang lebih baik karena pendidikan karakter dapat menjadi pengendali pikiran, sikap dan tindakan seseorang yang tidak baik. Nilai-nilai tersebut diintegrasikan dan menjadi bagian yang tak terpisahkan dalam mata pelajaran.

Terdapat 18 nilai pembentuk karakter dalam mata pelajaran yaitu 1) Religius, 2) Jujur,3)Toleransi, 4) Disiplin, 5) Kerja keras, 6) Kreatif, 7) Mandiri,8) Demokratis, 9) Rasa ingin tahu, 10)Semangat Kebangsaan, 11) Cinta Tanah Air, 12) Menghargai Prestasi, 13) Bersahabat/komunikatif, 14) Cinta Damai, 15) Gemar Membaca, 16) Peduli Lingkungan, 17) Peduli Sosial dan 18) Tanggung Jawab. ${ }^{8}$ Kedelapan belas nilai karakter tersebut dapat terbentuk dalam kepribadian siswa apabila ada kerja sama antar banyak pihak. Pemerintah, sekolah, masyarakat dan orang tua harus bisa menciptakan lingkungan siswa yang baik karena lingkungan dan interaksi yang baik akan membawa siswa ke dalam pengalaman yang baik pula.

\section{Nilai-nilai Agama Islam}

Nilai-nilai agama Islam memuat Aturan-aturan Allah yang antara lain meliputi aturan yang mengatur tentang hubungan manusia dengan Allah, hubungan manusia dengan manusia, dan hubungan manusia dengan alam secara keseluruhan'. Manusia akan mengalami permasalahan dalam hidupnya, jika dalam menjalin hubungan dengan sesama tidak mengikuti aturan yang telah ditetapkan oleh Allah.

${ }^{7}$ Adi Susilo, Sutarjo, Pembelajaran Nilai-Karakter, (Jakarta. Rajawali. Pers, 2014), hal.76.

${ }^{8}$ Narwanti, Sri, Pendidikan karakter, (Yogyakarta : Familia, 2011), hal. 29.

${ }^{9}$ Toto Suryana dkk.,Pendidikan agama Islam: untuk perguruan tinggi, (Bandung: Tiga Mutiara, 1996), hal. 148-150.

72 | FaLASIFA, Vol. 9 Nomor 1 Maret 2018 
Aspek nilai-nilai ajaran Islam dibedakan menjadi 3 jenis, yaitu nilai-nilai aqidah, nilai-nilai ibadah, dan nilai-nilai akhlak. Nilai-nilai aqidah mengajarkan manusia untuk percaya bahwa ada yang mengawasi dan memperhitungkan segala perbuatannya, yaitu Allah Yang Maha Esa dan Maha Kuasa sebagai Sang Pencipta. Dengan merasa bahwa Allah itu ada dan selalu mengawasi, maka manusia akan lebih taat dalam menjalankan perintah dan menjauhi larangan Allah. Nilai-nilai ibadah mengajarkan manusia untuk selalu mencapai rido Allah dalam setiap perbuatannya. Dengan nilai-nilai ibadah tersebut manusia akan lebih bersikap adil, jujur, dan suka membantu sesamanya. Nilai-nilai akhlak mengajarkan manusia untuk bersikap dan berperilaku sesuai norma atau adab yang benar dan baik, sehingga kehidupan manusia akan tenteram, damai, harmonis, dan seimbang. Dengan demikian nilai-nilai ajaran Islam mampu membawa manusia pada kebahagiaan, kesejahteraan, dan keselamatan manusia baik di dunia maupun kehidupan di akhirat kelak.

\section{Sikap dan Perilaku}

Sikap dapat didefinisikan sebagai kecenderungan afektif suka tidak suka pada sesuatu obyek sosial tertentu. Sebagai misal seseorang sadar bahwa merokok tidak bagi kesehatan, meskipun seseorang sangat menggemari rokok namun karena kesadaran kesehatan tersebut akhirnya mau tidak mau ia berhenti merokok. Ditinjau dari stabilitas kecenderungan afektif pada contoh di atas merupakan deskripsi dari "sikap".

Sikap merupakan ekspresi afek seseorang pada obyek sosial tertentu yang mempunyai kemungkinan rentangan dari suka sampai tak suka. Obyek-obyek sosial tersebut dapat beraneka ragam, mungkin orang, mungkin tingkah laku orang, mungkin lembaga kemasyarakatan, atau lainnya. ${ }^{10}$ Sikap ditinjau dari unsurunsur pembentuknya dapat dibedakan menjadi 3 hal yaitu sikap yang transformatif, transaktif dan transinternal. Sikap yang transformatif merupakan sikap yang lebih bersifat psikomotorik atau kurang disadari. Sikap yang transaksional merupakan sikap yang lebih mendasar pada kenyataan obyektif, sedang sikap yang transinternal merupakan sikap yang lebih dipedomani oleh nilai-nilai hidup. ${ }^{11}$

\footnotetext{
${ }^{10}$ Noeng Muhadjir,Pengukuran kepribadian: telaah konsep dan teknik penyusunan test psikometri dan skala sikap, (Yogyakarta: Rake Sarasin, 1992), hal. 95.

${ }^{11}$ Ibid,hal. 80.
} 


\section{Siti Mutmainah}

Di tinjau dari kategori sikap di atas, maka sikap seseorang terhadap sesuatu obyek tertentu dapat dipengaruhi oleh nilai-nilai yang dianut. Dengan demikian penanaman nilai-nilai agama Islam

sejak dini usia akan berpengaruh terhadap sikap anak dikehidupan dewasa nanti. Sikap biasanya dikaitkan dengan perilaku.Dalam pandangan Noeng Muhadjir perilaku tidak sekedar psikomotor tetapi merupakan performance kecakapan. Kecakapan berkaitan dengan aspek-aspek kecepatan, ketepatan, dan stabilitas suatu respon atau reaksi terhadap suatu stimulasi lingkungan. Beberapa jenis kecakapan yang berhubungan dengan kesuksesan seseorang dalam menempuh kehidupan, antara lain yaitu: kecakapan berempati (kecakapan yang berhubungan dengan tingkah laku sosial), kecakapan intelektual, kecakapan mental (ketahanan atau ketangguhan mental), kecakapan dalam mengelola hasrat atau motivasi, dan kecakapan dalam bertingkah laku sesuai etika masyarakat (watak baik buruk).

Berdasarkan beberapa jenis kecakapan tersebut di atas, perilaku yang dimaksud dalam kajian ini lebih cenderung mengarah pada perilaku yang berhubungan dengan kecakapan dalam bertindaksesuai akhlak dalam tinjauan Islam. Semisal perilaku yang selalu mengawali segala aktivitas dengan membaca Bismillah merupakan perilaku (akhlak) yang sesuai dengan etika/adab Islam.

\section{Semangat Kebangsaan}

Kata semangat berarti kekuatan (kegembiraan, gairah) batin, perasaan hati, nafsu (kemauan, gairah) untuk bekerja, berjuang, dan sebagainya. ${ }^{12}$ Sementara kata kebangsaan berarti ciri-ciri yang menandai golongan bangsa, perihal bangsa, mengenai (yang bertalian dg) bangsa, kedudukan (sifat) sebagai orang mulia (bangsawan), kesadaran diri sebagai warga dari suatu negara. ${ }^{13}$ Sejalan dengan pengertian tersebut, semangat kebangsaan adalah cara berpikir, bertindak dan berwawasan yang menempatkan kepentingan bangsa dan negara di atas kepentingan pribadi dan kelompoknya. ${ }^{14}$

Peserta didik harus diarahkan untuk memiliki semangat kebangsaan agar dapat mencintai negaranya sehingga dapat mengabdi kepada bangsa dan negara

\footnotetext{
${ }^{12}$ Alwi, Hasan, Kamus Besar Bahasa Indonesia, (Jakarta: Balai Pustaka, 2007), hal. 1025.

${ }^{13}$ Ibid, hal. 102.

${ }^{14}$ Anas Salahudin, IrwantoAlkrienciehie, Pendidikan Karakter, (Bandung : CV Pustaka Setia, 2013), hal. 111.
}

74 | FALASIFA, Vol. 9 Nomor 1 Maret 2018 
selain mengabdi kepada agama yang dianut. ${ }^{15}$ Indikator pencapaian pembelajaran dari nilai karakter semangat kebangsaan adalah bekerja sama dengan teman yang berbeda suku/etnis dan mengaitkan materi pelajaran dengan peristiwa yang menumbuhkan rasanasionalisme dan patriotisme. ${ }^{16}$ Indikator semangat kebangsaan dibagi menjadi dua yaitu indikator kelas dan indikator sekolah. ${ }^{17}$ Indikator sekolah untuk karakter semangat kebangsaan yaitu :

1. Melakukan upacara rutin sekolah.

2. Melakukan upacara hari-hari besar nasional.

3. Menyelenggarakan peringatan hari kepahlawanan nasional.

4. Memiliki program melakukan kunjungan ke tempat bersejarah.

5. Mengikuti lomba pada hari besar nasional

Sedangkan untuk indikator semangat kebangsaan di dalam kelas yaitu:

1. Bekerja sama dengan teman sekelas yang berbeda suku, etnis, status sosialekonomi.

2. Mendiskusikan hari-hari besar nasional.

\section{Pembelajaran bahasa Indonesia}

Manusia belajar bahasa karena kebutuhan untuk berkomunikasi dengan orang-orang disekitarnya.Fungsi bahasa yang utama adalah sebagai alat komunikasi seseorang. Untuk itu pembelajaran, peseta didik dituntut untuk mampu menggunakan bahasa Indonesia yang baik dan benar untuk keperluan berkomunikasi dalam berbagai situasi. ${ }^{18}$ Dalam kegiatan berkomunikasi, peserta didik pun dituntut untuk menggunakan bahasa yang mencerminkan nilai-nilai karakter yang berhubungan dengan nilai-nilai perilaku manusia dalam hubungannya dengan Tuhan Yang Mahaesa, diri sendiri, sesama manusia, dan lingkungan serta nilai-nilai ciri khas kebangsaan.

Penekanan utama dalam pembelajaran dengan pendekatan komunikatif adalah mengaitkan keterampilan peserta didik untuk berkomunikasi dengan bahasa. ${ }^{19}$ Dalam hal ini kemampuan berkomunikasi perlu ditekankan dalam pembelajaran bahasa, pengetahuan tata bahasa dan kosa kata bukanlah tujuan

\footnotetext{
${ }^{15}$ Yaumi, Muhammad, Pendidikan Karakter: Landasan, Pilar, dan Implementasi, (Jakarta: Prenada Media Group, 2014), hal. 103.

${ }^{16}$ Narwanti, Sri, Pendidikan karakter, (Yogyakarta : Familia, 2011), hal. 67.

${ }^{17}$ Kemendiknas, Rencana Aksi Pendidikan Nasional Pendidikan Karakter, (Jakarta: Balitbang dan Puskur, 2010), hal.27.

${ }^{18}$ Slamet, St. Y., Dasar-Dasar Pembelajaran Bahasa dan Sastra Indonesia di Sekolah Dasar, (Surakarta: LPP UNS dan UPT, 2007), hal. 6.

${ }^{19}$ Ibid, hal. 7.
} 
Siti Mutmainah

utama dalam pencapaian belajar bahasa. Dengan kemampuan komunikatif tersebut, peserta didik dapat mencerminkan nilai-nilai karakter yang dianutnya sebagai makhluk sosial dan makhluk berbudaya.Bahasa Indonesia sebagai lambang kebanggaan nasional, maka Bahasa Indonesia memancarkan nilai-nilai sosial budaya luhur bangsa Indonesia. ${ }^{20}$ Guru Bahasa Indonesia sebagai fasiltator dan motivator dalam pembelajaran harus bangga, menjunjung tinggi, serta mempertahankan bahasa Indonesia. Hal ini bertujuan agar dalam berkomunikasi siswa dapat menunjukkan sikap kecintaan dan kebanggaannya terhadap bahasa Indonesia. Karena dengan menggunakan Bahasa Indonesia yang baik dan benar akan dapat diketahui identitas pemakainya. Metode pembelajaran yang digunakan harus dapat mengaktifkan peserta didik sehingga menunjukkan keaktifan peserta didik dalam mengemukakan gagasannya baik secara individu maupun kelompok. Dengan kegiatan tersebut guru akan dapat mengawasi, mengotrol, mengevaluasi, dan mengoreksi Bahasa yang digunakan peserta didik dengan mengintegrasikan dengan nilai-nilai sosial budaya/karakter bangsa Indonesia.

\section{Nilai Islam dan Nilai Kebangsaan dalam Pembelajaran Bahasa Indonesia}

Pembelajaran Bahasa Indonesia merupakan salah satu materi pelajaran yang sangat penting di sekolah. Tujuan pembelajaran bahasa Indonesia adalah agar siswa memiliki kemampuan berbahasa Indonesia yang baik dan benar serta dapat menghayati bahasa dan sastra Indonesia sesuai dengan situasi dan tujuan berbahasa serta tingkat pengalaman siswa sekolah dasar. ${ }^{21}$ Pembelajaran Bahasa Indonesia dalam kontes pembinaan agama islam dan kebangsaan dilakukan dengan pemilihan bahan ajar yang sesuai dengan prinsip pembinaan islam dan kebangsaan. Selain itu perlu diadakan pembinaan terhadap guru bahasa Indonesia tentang islam dan kebangsaan serta mnekankan peran guru dalam mentransformasikan nilai agama dan kebangsaan melalui pembelajaran bahasa Indonesia. Dengan demikian, guru bahasa Indonesia disamping mengajarkan bahasa juga mengajarkan ajaran islam dan menumbuhkan jiwa nasionalisme pada siswa.

\section{Nilai-Nilai Islam dalam Pembelajaran Bahasa Indonesia}

Berikut ini akan dipaparkan pengajaran bahasa yang berkarakter islami dipilah berdasarkan keterampilan berbahasa, yaitu:

\footnotetext{
${ }^{20}$ Muslich,Masnur dan I gusti Ngurah Oka, Perencanaan Bahasa pada Era Globalisasi, (Jakarta: Bumi Aksra, 2010), hal. 30.

${ }^{21}$ Akhadiah dkk.,Bahasa Indonesia I, (Jakarta:Depdikbud, 1991), hal. I
}

76 | Falasifa, Vol. 9 Nomor 1 Maret 2018 
Nilai Islam dan Nilai Kebangsaan...

1. Keterampilan membaca

Dalam surat al-alaq 1-5 terdapat nilai-nilai religius pembelajaran membaca.

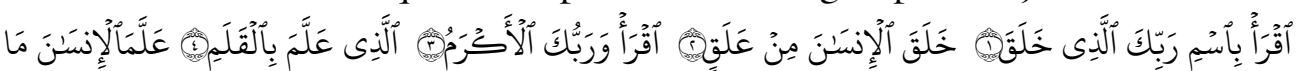

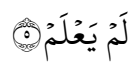

Artinya:

Bacalah dengan (menyebut) nama Tubanmu yang menciptakan, Dia telah menciptakan manusia dari segumpal darah. Bacalah, dan Tuhanmulah Yang Mabamulia, Yang mengajar (manusia) dengan pena. Dia mengajarkan manusia apa yang tidak diketahuinya.

Berdasarkan ayat tersebut membaca menjadi salah satu keharusan. Seperti yang tercantum dalam ayat pertama yakni "iqra" , "bacalah" merupakan perintah membaca. Membaca merupakan perintah Tuhan, karena membaca merupakan jendela ilmu pengetahuan. Tanpa membaca manusia akan buta ilmu, selain itu melalui surat tersebut dapat dijadikan senjata oleh guru untuk menyadarkan siswa bahwa membaca merupakan salah satu bentuk ibadah.

Guru juga dapat memilih bahan bacaan yang syarat akan pengetahuan agama. Misalkan saja dalam materi membaca ekstensif teks. Teks yang disajikan oleh guru harus yang bernuansa islami. Jadi selain belajar membaca dengan menemukan ide pokok dalam paragraf, siswa juga dapat memetik hikmah dari bahan bacaannya.

2. Keterampilan menyimak

Menyimak merupakan media untuk menyerap informasi baik berupa gagasan, ide dll. Dalam proses pembelajaran guru dapat menyajikan sumber bahan yang disimak berupa audiovisual. Misalkan saja video pidato keagamaan. Dalam hal ini siswa dapat belajar menyimak dengan baik, selain itu juga dapat mengambil pesan moral dan agama yang disampaikan oleh narasumber.

3. Keterampilan berbicara

Pembicaraan yang baik dalam islam adalah pembicaraan yang memiliki manfaat. Seseorang lebih baik diam atau banyak berzikir daripada membicarakan hal-hal yang tidak bermanfaat, bergibah misalnya. Landasan berbicara yang baik dalam al-quran terdapat pada surat An-Nahl ayat 125 yang berbunyi:

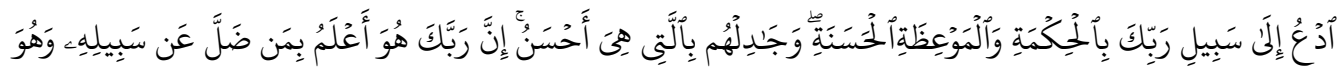

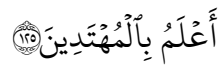

FaLASIFA, Vol. 9 Nomor 1 Maret 2018 | 77 
Siti Mutmainah

Artinya:

"serulah manusia kepada jalan Tuban-mu dengan bikmah dan pelajaran yang baik dan bantablah mereka dengan cara yang baik. Sesunggubnya Tubanmu Dialah yang lebih mengetahui tentang siapa yang tersesat dari jalan-Nya dan Dialah yang lebih mengetahui orang-orang yang mendapat petunjuk.”

Dalam pembelajaran bahasa Indonesia keterampilan berbicara perlu dikembangkan terutama untuk menumbuhkan karakter islami pada siswa. Misalkan saja pada materi wawancara. Guru bisa menyajikan tema wawancara dengan nuansa islam, atau dengan menjadikan tokoh agama sebagai narasumber wawancara siswa. Hal ini selain dapat menambah pengetahuan siswa dalam keterampilan berbicara, siswa juga memperoleh pengetahuan tentang tema islam yang diangkat.

4. Keterampilan menulis

Menulis merupakan cara efektif untuk menyampaikan ide dan gagasan. Selama informasi yang disampaikan bermanfaat bagi orang lain, menulis dapat dikategorikan sebagai bagian dari dakwah. Seperti yang terdapat dalam surat AnNahl berikut ini bahwa menyampaikan kebenaran merupakan suatu perintah Allah SWT.

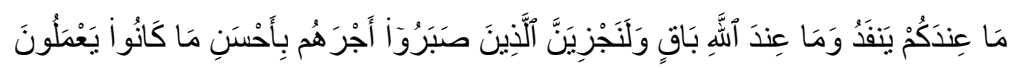
Apa yang di sisimu akan lenyap, dan apa yang ada di sisi Allah adalah kekal. Dan sesunggubnya Kami akan memberi balasan kepada orang-orang yang sabar dengan pahala yang lebih baik dari apa yang telah mereka kerjakan.

Dalam pembelajaran bahasa Indonesia, sering kali keterampilan menulis menjadi hal yang sulit bagi siswa. Karena memang dalam menulis terutama mengarang memerlukan keterampilan dan wawasan yang luas. Untuk diintegrasikan dengan nilai-nilai islam, guru dapat mengajarkan siswa menulis dengan dikaitkan dengan tema keislaman. Misalkan saja dalam standar kompetensi menulis pengalaman pribadi. Guru bisa mengarahkan siswa untuk menulis pengalaman mengaji saat di pesantren kilat misalnya. Dari situ sedikit banyak siswa banyak menuliskan pengalaman spiritualnya selama di pesantren kilat yang ia ikuti.

5. Mengapresiasi karya sastra

Pada dasarnya pembelajaran mengapresiasi karya sastra justru lebih mudah untuk mengintegrasikannya dengan pendidikan agama. Salah satunya dengan cara memilih karya sastra yang bertema keislaman. Selain itu diperlukan juga landasan moral untuk mencontoh perilaku orang lain secara benar, landasan moral ini bisa dilihat dalam surat An-Nahl ayat 44:

78 | Falasifa, Vol. 9 Nomor 1 Maret 2018 
Nilai Islam dan Nilai Kebangsaan...

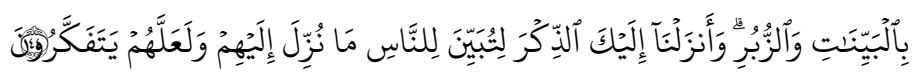

Artinya:

keterangan-keterangan (mukjizat) dan kitab-kitab. Dan Kami turunkan kepadamu Al Quran, agar kamu menerangkan pada umat manusia apa yang telah diturunkan kepada mereka dan supaya mereka memikirkan.

Contohnya dalam standar kompetensi menemukan unsur intrinsik dalam novel, guru dapat menyajikan novel-novel yang bernuansa islami misalkan saja Di Bawah Lindungan Ka’bah, Robohnya Surau Kami, Negeri 5 Menara, dll. Dalam hal ini selain dapat menemukan unsur instrinsik dalam novel siswa juga dapat mengambil amanah dan ilmu keislaman yang dapat ia peroleh dari novel yang dibaca.

\section{Nilai Kebangsaan dalam Pembelajaran Bahasa Indonesia}

Berikut ini akan dipaparkan pengajaran bahasa yang berkarakter kebangsaan:

1. Pemberian materi ajar kebahasaan yang dapat menghubungkan guru, pesertadidik, dan lingkungan, misalnya peserta didik harus membuat laporan hasilwawancara terhadap guru, teman, dan masyarakat sekitar sekolah tentang "gotong royong". Dengan tema tersebut dapat menumbuhkan rasa tanggung jawab jawab, kerja sama, toleransi, kepedulian dan cinta tanah air.

2. Pemberian tugas penganalisisan dan pengapresiasian karya pengajaran bahasayang mengandung semangat kebangsaan, misalnya Bumi Manusia karya Pramoedia Ananta Toer yang menunjukan betapa pentingnya belajar dan semangat kebangsaan, Pulang karya Leila $S$ Chudori yang menunjukkan cinta tanah air dan semangat kebangsaan, dll.

3. Penyajian sastra dapat juga dikemas dengan menyajikan cerita-cerita fiktif yang bertema pancasila. Hal tersebut dapat menumbuhkan rasa nasionalisme sehingga terlahir nilai-nilai kebangsaan dalam pembelajaran bahasa Indonesia. Misalkan saja cerita fiktif mengenai garuda yang bisa diaplikasikan dalam bentuk dongeng ataupun teater berikut:

"Alkisah garuda itu bukan sejenis burung, melainkan nama burung. Burungnya ulung atau elang atau rajawali. Ia putra dari seorang ibu yang menderita hidupnya karena diperbudak oleh kakak kandungnya. Mereka berdua menempuh sayembara di antara mereka berdua menempuh sayembara diantar mereka berdua untuk menebak apa warna kuda yang sedang berlari kencang di gigir carawala. Sang kakak mengatakan hitam. Adiknya yakin

FALASIFA, Vol. 9 Nomor 1 Maret 2018 | 79 


\section{Siti Mutmainah}

putih. Bagi yang tebakannya salah, ia menjadi budak bagi yang tebakannya kurang benar. Harus disuruh apa saja.

Ketika saatnya tiba, ternyata ekor kuda itu berwarna putih. Kakanya tidak mau kalah. Ia punya peliharaan dan bersahabat dengan naga. Maka, ia minta naga-naga itu menyembur atau menyemprotkan ludah ke ekor kuda agar warna putihnya hilang. Singkat kata akhirnya ekor kuda itu cenderung hitam dibanding putih. Maka, sang adik kalah dan menjadi budak kakaknya.

Sampai suatu hari sang adik mempunyai anak yang ia namakan Garuda. Bayi ini kekasih para dewa. Di dalam dirinya diisi berbagai keistimewaan dan kesaktian. Dan, sang ibu tahu memang tahu bahwa sang putra kelak meerdekakannya dari perbudakan.

Singkat cerita, Garuda bertapa dan mendapat petunjuk bahwa untuk membebaskan sang ibu, ia harus menemukan Air Amerta. Melalui perjuangan yang sangat gigih dan benar-benar pantang mundur, akhirnya Garuda diperkenankan oleh dewa untuk menemukan air itu disebuah pulau terpencil. Sang kakak panik karena ia harus membebaskan si adik.

Secara brutal, sang kakak coba merebut kantong air Amerta sampai sobek dan air itu tercecer menciprati rerumputan tinggi. Karena dibasahi oleh Amerta, rumput itu memiliki kekuatan langit untuk menolak bala dan bencana. Itulah sebabnya, ia bernama Alang-alang. Ia mampu menjadi penghalang bencana.

Alang-alang adalah rakyat kecil yang dipandang remeh, diinjak-injak, direndahkan, dan dianggap tak berguna. Tetapi sepanjang waktu Alang-alang tidak pernah diberitakan mati. Yang selalu akhirnya mati adalah penguasa yang menginjak-nginjaknya.

Juntrungan sejarahnya jelas sekarang. Ibu Pertiwi, yang disandera dan diperbudak oleh saudaranya sesama manusia, sedang menanti perjuangan Garuda untuk membebaskannya dari perbudakan yang tak ada habisnya.”22

4. Perlu adanya perancangan tugas-tugas yang memberdayakan karakterkebangsaan kepada peserta didik. Misalnya, memberikan tugas kelompokberupa laporan analisis hasil wawancara kepada kaum duafa di lingkungannya. Selain peserta didik menerapkan teori teknik wawancara dantata tulis laporan, mereka pun disentuh untuk mewujudkan kepedulian kepada orang kecil.

5. Pemberian tugas berupa bermain peran juga dapat memberdayakan karakter kebangsaan peserta didik. Dengan bermain peran, merekadapat berkreasi dalam memainkan watak, bersinergi dengan yang lain, melatihpenghayatan

\footnotetext{
${ }^{22}$ Emha Ainun Nadjib, Kiai Hologram, (Yogyakarta:Bentang, 2018), hal. 202-204.
} 
peran, melatih daya kepekaan, dan melatih untukmengaktualisasikan diri. Dalam pembelajaran bahasa, misalnya,memainkan peran sebagai seorang tokoh pahlawan atau seorang tokoh fiktif yang berjiwa pancasila.

6. Dengan pendekatan karakter kebangsaan, kita dapat mendesain aturan dikelas. Misalnya, aturan tidak boleh mencontek, aturan tidak boleh terlambat,aturan berpakaian rapi, aturan memakai sepatu, aturan tidak mengaktifkanhandphone, tidak makan atau minum di kelas, berdoa sebelum dan sesudahpembelajaran, dan aturan lain yang dapat memberdayakan keterampilankarakter kebangsaan. Dalam pembelajaran bahasa, kita dapat menerapkanaturan "zona penggunaan bahasa baku, baik, dan benar" di dalam kelas.

\section{Korelasi Nilai Islam dan Nilai Kebangsaan dalam Pembelajaran Bahasa Indonesia}

Seperti yang telah dibahas sebelumnya bahwa pembelajaran bahasa Indonesia dapat diintegrasikan dengan nilai islam dan nilai kebangsaan. Disisi lain juga perlu diketahui bahwa terdapat korelasi antara Pendidikan Agama Islam dan Pendidikan Kewarganegaraan, keduanya memiliki sedikit kesamaan dalam hal tujuannya yaitu menanamkan nilai-nilai kehidupan bermasyarakat dan bernegara serta budi pekerti atau akhlak yang luhur. Di samping menanamkan sikap budi pekerti yang luhur, Pendidikan Kewarganegaraan juga membentuk anak didik agar dapat memahami,mengamalkan dan melestarikan nilai-nilai Pancasila sehingga menjadi warga negara yang baik dan bertanggung jawab mencakup pada dimensi pengetahuan kewarganegaraan, ketrampilan kewarganegaraan dan nilainilai kewarganegaraan. Sedangkan didalam Pendidikan Agama Islam, untuk kepentingan pendidikan dalam mencapai dan mengamalkan moral atau akhlak dalam kehidupan sehari-hari yaitu dengan melalui proses ijtihad, para ulama mengembangkan materi Pendidikan Agama Islam pada tingkat yang lebih rinci. ${ }^{23}$

Korelasi antara ketiga mapel tersebut dapat dicontohkan sebagai berikut. Dalam standar kompetensi menulis pengalaman pribadi, guru dapat menentukan tema pengalaman berjihad selama belajar di pesantren kilat. Dari sini siswa akan mencari tahu dan menambah wawasan seperti apa jihad dalam islam. Guru dapat mengarahkan bahwa berjihad bagi seorang muslim terutama pelajar adalah belajar yang baik, disiplin, dan banyak berdoa. Hal ini juga dapat menambah kosa kata baru bagi siswa bahwa makna dari jihad yaitu berjuang dengan sungguh-sungguh.

${ }^{23}$ Depdiknas, Undang-undang RI No.20 tahun 2003.(tentang sistem pendidikan nasional,2003), hal.2

FaLASIFA, Vol. 9 Nomor 1 Maret 2018 | 81 
Siti Mutmainah

Jihad bukan saja dapat diartikan perang, terlebih seperti yang telah dilakukan oleh para teroris di negeri ini. Justru yang dilakukan mereka bukanlah berjuang menegakkan agama islam tapi justru memperkeruh keadaan negeri ini. Tindakan tersebut tidak patut ditiru karena sudah merugikan agama ataupun bangsa. Pelakunya tidak memiliki jiwa yang mencintai kedamaian dan tidak memiliki sikap toleransi dalam berbangsa dan bernegara.

Contoh lain misalnya dalam keterampilan sastra pada materi indentifikasi puisi. Guru dapat menyajikan puisi yang bernilai islam sekaligus bernilai kebangsaan. Misalkan puisi berikut:

\section{Ibu Indonesia Kini}

Dulu ku tak tahu syariat Islam

Karena cinta kasih-Nya kini kutahu

Keindahan sari konde Ibu Indonesia yang lalu

Kini kugantikan dengan selembar kain

Yang tak menghilangkan kecantikan dan kebangsaanku

Julurannya suci melindungi kesucianku

Kain yang membungkus mahkotaku itu

Menyatu dengan kodrat wanitaku yang amat berharga

Ia tak merusak tanah airku

Kibarannya ketika tertiup angin laut, bak lambaian nyiur di pantai

Lihatlah Ibu Indonesia kini

Pandangannya jernih dan lurus ke depan

Kecintaannya terhadap negeri Indonesia tidak mengkhilafkannya akan negeri akhirat

Kain yang menjulur dari kepalanya tidak menggores kecantikan bangsanya

Ia tak menghalangi aktifitas, kreativitas, intelektualitas bahkan semakin anggun dibuatnya

Selamat datang di negeri Indonesia, bumi Allah...

Kini kutahu syariat Islam

Suara azdan yang setiap waktu menggema

Merpekokoh pasak bumi dari murka Tuhan

Sangat elok melebihi alunan nada di seluruh penjuru dunia

Gemulai jemari memetik tasbih begitu lihai

Bibir basah menyebut asma-Nya

Beriringan dengan kicauan burung yang berzikir dan deburan ombak pantai nusantara

Pandanglah bumi Allah ini...

82 | FaLASIFA, Vol. 9 Nomor 1 Maret 2018 
Saat pandanganmu semakin pudar dengan akhirat karena terlalu sibuk dengan dunia

Bumi pertiwi ini, dan semua kemolekan semesta bangsa ini

Ada... karena karunia Tuhan Yang Maha Esa

Dari puisi tersebut menunjukkan bahwa ada korelasi antara syariat islam dengan nilai kebangsaan. Karena memang tidak dapat dipungkiri bahwa sejarah kemerdekaan negeri inipun tidak lepas dari peran umat islam. Para pahlawan yang tidak sedikit dari mereka adalah kaum muslim, telah mengorbankan jiwa raganya demi kemerdekaan negeri ini. Karena itulah Indonesia dan Islam tidak dapat dipisahkan, adanya Indonesia karena Allah SWT. Dan selain contoh di atas masih banyak lagi pembelajaran bahasa Indonesia yang berkaitan dengan nilai islam dan nilai kebangsaan.

\section{KESIMPULAN}

Berdasarkan pemikiran yang dikembangkan dalam deskripsi di atas, bisa ditarik kesimpulan sebagai berikut. Pembinaan keimanan dan ketakwaan serta nilai kebangsaan melalui pembelajaran bahasa Indonesia bisa dilakukan dengan dua cara. Pertama, transformasi nilai-nilai agama dan nilai kebangsaan oleh guru secara implisit atau eksplisit dalam proses pembelajaran bahasa. Di sini guru hendaknya menguasai relevansi ajaran agama dengan prinsip-prinsip bahasa. Kedua, pemilihan bahan ajar yang mendukung terintegrasinya antara Imtaq, Iptek, dan nasionalisme. Guru misalnya, bisa melakukan hal tersebut dalam pemilihan wacana dan jenis bacaan untuk para siswanya.

\section{DAFTAR PUSTAKA}

Al Qur'an

Adi Susilo, Sutarjo. 2014.Pembelajaran Nilai-Karakter. Jakarta: Rajawali Pers.

Ainun Nadjib, Emha.2018. Kiai Hologram. Yogyakarta:Bentang

Akhadiah, Sabarti,dkk. 1991. Bahasa Indonesia I. Jakarta:Depdikbud.

Alwi, Hasan. 2007. Kamus Besar Bahasa Indonesia. Jakarta: Balai Pustaka

Benninga, J.S.1991.Moral, Character, And Civic Education In The Elementary. School. London: Teachers College Press.

Depdiknas .2003. Undang-undang RI No.20 tahun 2003.tentang sistem pendidikan nasional

Kemendiknas . 2010. Rencana Aksi Pendidikan Nasional Pendidikan Karakter.Jakarta: Balitbang dan Puskur. 
Siti Mutmainah

Lickona, Thomas. 2013. Pendidikan Karakter-Panduan Lengkap Mendidik Siswa Menjadi Pintar dan Baik (Terjemahan dari Educating for Character, 2008 oleh Lita S), Bandung: Nusa Mesia.

Muhadjir, Noeng. 1992. Pengukuran kepribadian: telaah konsep dan teknik penyusunan test psikometri dan skala sikap. Yogyakarta: Rake Sarasin.

Muslich, Masnur dan I gusti Ngurah Oka. 2010. Perencanaan Bahasa pada Era Globalisasi. Jakarta: Bumi Aksra.

Narwanti, Sri.2011. Pendidikan karakter. Yogyakarta : Familia.

Salahudin, Anas danIrwanto Alkrienciehie. 2013. Pendidikan Karakter. Bandung : CV Pustaka Setia

Slamet, St. Y.. 2007. Dasar-Dasar Pembelajaran Bahasa dan Sastra Indonesia di Sekolah Dasar. Surakarta: LPP UNS dan UPT.

Toto Suryana, Af, A.,dkk. 1996. Pendidikan agama Islam: untuk perguruan tinggi. Bandung: Tiga Mutiara

Yaumi, Muhammad. 2014. Pendidikan Karakter: Landasan, Pilar, dan Implementasi. Jakarta: Prenada Media Group.

Darajat, Zakiah. 1993. Membina Nilai-nilai Moral di Indonesia. Jakarta: Bulan Bintang. 